宇治茶の勞働力の特色とその季節的移動

\title{
〔谷岡武 雄〕
}

1. 宇治茶の生産地域 5 月上句より 6 月にかけて, 山城盈地の南部，宇治町を 中心とする附近の洪積台地一圆を覆ら老茶樹の覆架は，宇治茶の特異な载培景觀を示 するのとして知られている。ところで此處より南に進んで木津川上流に至り，或は

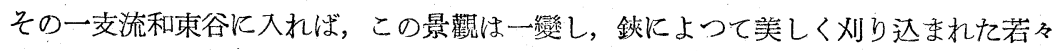
しい茶樹が，㠅を被らず山腹に列をなして低く連る。この二つの景觀の對比は，あら ゆる意味で宇治茶の生產地域がもつ, 停滞と躍進, 老巧々新銃の地域的分化のあらわ れであつて，茶業勞衝力る亦それに應じれ相違を示しているのである。本地域に於け

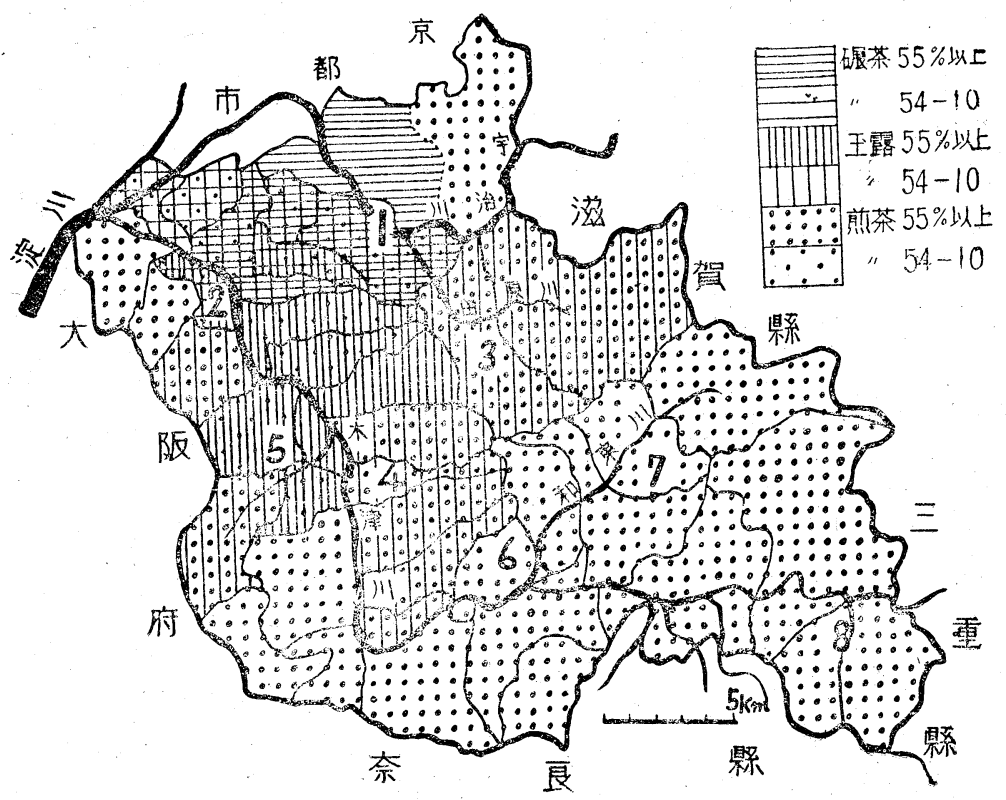

第 1 圖 製茶各品種別应額の賞該町村總產額飞對する割合の分布 (1942) 
る荣樹の溨培は，宇治・木津兩河川流域の洪唒台池に或は木津川氾濫原に，或はそれ らの霧深き小支谷に見られるが，茶の生蒦條件等を考慮して次の如き地域區分をなす ことができる(第 1 圖參照)。

1. 宇治碾茶・王露地域

3. 田原谷玉露・朔茶地域

5. 木津川西部玉露・煎茶地域

7. 和束谷䤼刈煎茶地域
2. 木津川下流玉露・碾茶地域

4. 木津川東部煎茶・王露地域

6. 木津川中流煎茶地域

8. 木津川上流鋏灲煎茶地域

これを概括すれば. 碾茶・玉露の生產される北部の宇治・久世兩郡と鉸刚煎茶地域た

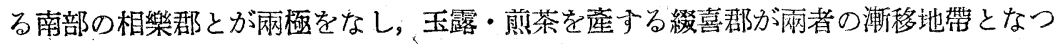
ている。

2. 茶業勞働の種類とその季節的集中性 茶業勞働を施肥・耕耘・除草・元 出し・病蟲防除・剪枝・堀切り・根切り・被覆・箄取り・小屋修理等を內容 とする茶樹の栽培，1番・2 番の茶葉の摘採，芽運び・生葉選・蒸熱・製造 等の茶の製造並びに製茶加工の 4 程に分つならば，全勞働力の大牛はこの摘 採乙製造と飞渻費され，しか子とれが宇治茶の場合，5月中旬より6月上旬 にかけての僅か20日間に，極度に集中しているのである。例えば玉鼠園 1 町

\section{第 1 表}

\begin{tabular}{|c|c|c|c|c|c|c|c|}
\hline $\begin{array}{l}\text { 農家 } \\
\text { 番:號 }\end{array}$ & 法 & 栽培勞力 & 摘採勞力 & 製造勞力 & 計 & $\begin{array}{l}\text { 製茶貫當 } \\
\text { 撕探勞力 }\end{array}$ & $\begin{array}{l}\text { 製茶貫賞 } \\
\text { 製造勞力 }\end{array}$ \\
\hline A & 玉露手摘手揉 & $30 \%$ & $35 \%$ & $35 \%$ & $100 \%$ & 1.8 人 & 1.9 人 \\
\hline B & 煎茶手摘牛機 & 22 & 53 & 25 & 100 & 1.4 & 0.6 \\
\hline C & 玉露手摘牛機 & 25 & 47 & 28 & 100 & 2.2 & 1.3 \\
\hline $\mathrm{D}$ & 煎茶手摘全機 & 31 & 53 & 16 & 100 & 1.2 & 0.3 \\
\hline $\mathrm{E}$ & 玉露手摘全機 & 30 & 49 & 21 & 100 & 2.1 & 0.9 \\
\hline $\mathbf{F}$ & 碾茶手摘全機 & 33 & 36 & 26 & 100 & 1.8 & 1.7 \\
\hline G & 煎茶鋏杊全機 & 49 & 30 & 21 & 100 & 0.3 & 0.2 \\
\hline
\end{tabular}

（註）昭和14年度茶業經營調查表(京都府茶業聯合會調查)を基礎として算定 
步を經營する，1茶業家の用いる年間勞働力の $62 \%$ は，5月の製茶飞充てら れている(昭和16年宇治郡東宇治町茶業組合調查に上る)。しかしねがら，か〉る 茶業勞働力8，摘採・製法・製品の如何により，季節的集中度を異にしてい

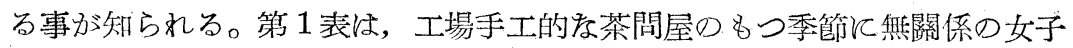
加工勞力を除き，製茶全工程の主要をる組合せを，機械使用の點で低級をも のより配列し, 勞働力の比率を求めたものである。とれによれば, 機械に低 存するす口程製造勞力は少くてよいが，栽培勞力の比重は高まり，また玉 露・碾茶索ぼ高級品の製造程, 多くの製造勞力を必要こしている。更て鋏刚


まいのである。いすれれせよ茶業勞働は年 1 度の茶葉の摘採と製造とがその 中心学している。

3. 茶業勞働力の諸構成、今炏の戰爭汇よる甚しい混笘を除き, 一應戰前 の常態について茶業勞働力の諸構成を檢討すると, 昭和14・15兩年度に各町

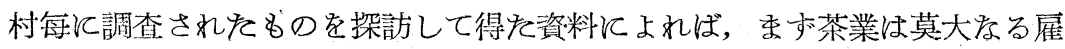
傭勞衝力を基礎として成立している事に氣付汃れる。しかもその低存の程度 は，製茶品種によつて異つており，例えば玉露は全熒力の $67 \% ，$ 碾茶は77\%

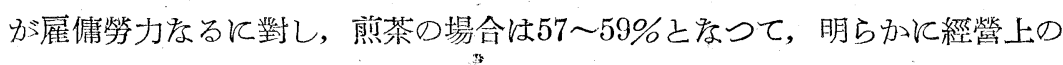
相違を示している。てれを地域的にみれば，宇治・久世兩郡の雇傭勞力はを れぞれ 85, 80\%ですつて，緅喜郡57\%，鈇㺫煎茶の相樂郡34\%となつている。 更飞同年の全雇骕勞劺力（賽人員）は 15,187 人で，その $15 \%$ は地域外よりの 入稼者であり，昭和 3 年の調查飞比し，地域內 $26.6 \%$ 減，地域外 $54.1 \%$ 減之 孝つている。

次にてれらの勞㗢力口男女別構成をみるに, 全所要勞力 3 萬 8 千人の中, その70\%は女子によつて占められている。てれは主として茶葉の摘採に從う

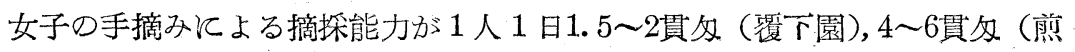


茶）をるに對し，男子の從事する製造は遥かに大なる能率をあげらるためで あつて，てれが手揉製法によつを封代ならば，男子の焙爐師は 1 人 5 貫斥の

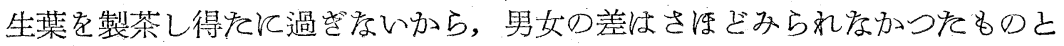
思われる。しかるに鋏㺫りとなると，てれには女子が雇傭されね故，男子の 比率はか存り上杽する。一般に自家勞力は主しして製造に從事するものであ るが，その28\%は製造男子，13\%は茶摘男子，44\%は茶摘女子亡をつて, 雇 傭勞力の場合の，製造男子 $12 \%$ ，茶摘男子 $5 \%$ ，茶摘女子 $75 \%$ 亿比すれば， 男子の役割が一層重要となつてくる。てれらを地域的にみれば，北部の復下 園地域では男女の比が 1:4 まると對し，機械化の進えだ，主こして自家勞力 にて經營される南部の鋏㺫煎茶地域では，それが 4:6:5 となつている。

茶業勞働力は最近になつて著しく老年化するに至つた。郎ちとの年龄構成 をみるに，20歲以下 $13 \% ， 21 ４ 0$ 歲35\%，41歲以上 $51 \%$ とつて，昭和 3 年 のそれぞれ18\%，46\%，36\%に比し，高年者の占める率が豫想外飞高く度つ ている。てれは戰時の例外的現象では度くして，往年のいつしか年中行事の 1つとまでをつね茶業出稼が，老年者にしか魅力を持を宗くをつねをめと思 われる。な和本地域では 2 番茶の製造が盛んでるいため，てれの所要勞力は 鈇刚煎茶地域でのみ 1 番茶の70\%を要しているが，他㤌いずれも30\%以下に とがすつている。

4. 茶業焱働力の季節的移動 茶園一面に寚茶の終つた頃, 大きい包を背 負つた老幼男女の群が，續ふとこの地てりり來る。彼らはこの地の人ふに上 つて通勤勞働者たる「通い」と佳込みの「之委りや秀」及び場所及及定渡り 步之「渡り」こに分けられている。就中「通い」は周邊の農村よりの出稼者 で, 最も大なる比率を占め, 例えば昭和 14 年飞括ける全雇傏勞力の $84 \%$ はと のグループイ屬するものであつた。然しながら今日程に食糧事情の笨迫せぬ 頃には，激しい勞働のため隣接町村出身者さえ「之李りや李」之をるものが 
多かつを。㴗之んぞ「之委りや委」に屬する府外上りの出稼者中，最も多数 なの怡奈良縣出身者で，その $48 \%$ を占わ，以下滋賀・三重・兵庫・大阪・靜 岡の順とをつている。出稼地の事情を知るをめ; 奈良縣の若干の町村につき 農業勞働の季節的變化を調查した結果，5月上旬の粐委きが終つて 6 月初め の麥の收穫までの暫時の間に，熒力に餘裕の生晾事を明らかになし得た。 てれらの茶業出秝者には 2 種あつて, そのうち第 1 ののは鄉里に耕地も持

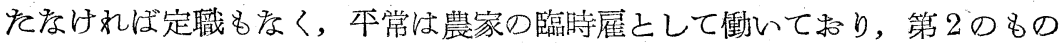
は通常の農民で，上述の㟻時の農事の餘㗇を利用するものである。

晚霜の終了期が地域によつて相違するため，茶の摘採開始期に若干のホれ を生亦る。まづ5月 5〜 10 日飞始委る早場の木津川中流・西部・東部地域 には, 出稼の先發群が訪れ，まだ製茶の始まらをい山間部よりも谷を下つて



第 2 圖 宇治茶の勞働力の季節的移動經路 


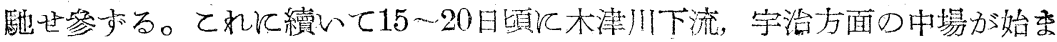

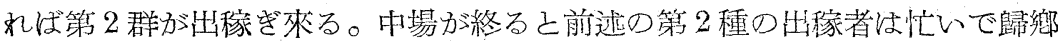
ナるが，殘餘は宇治川定遡るか，木津川沿岸より信樂街道によつて曰原谷に 大り，晚場の製茶に渡つていく。これ亡別系統のものも和束谷を遡つて奥地 に進斥，更に府囬境を超えて，漸く始つた滋賀縣甲賀郡朝宮地方の製茶に向 いと〉にて田原各采統のものと合流するのである。滋賀縣にては 2 番茶， 3番茶と續く故，そのず゙てを渡り步いて郷里に歸れば，もはや８月も中葉

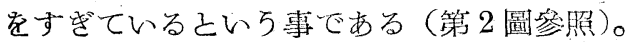

茶業出稼は明治時代には「丹波さん」と呼ばれ，元來酒造出稼も多い舊丹

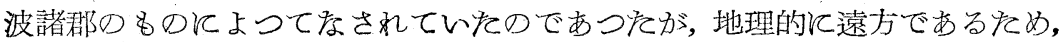

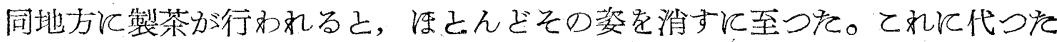
のが大和地方よりの出稼人達である。彼らは手揉時代には,「䏤元」に統卒さ

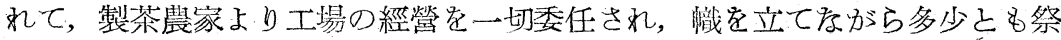
日氣分を含んだ賑かな工場手工に各自の腕を競つねものであつた。眮元」の 下には，茶摘み・芳運び・繁し・毒もみ・二番師・仕上師の諸階級があつて， 最後者は仕上工程を司る最上級者乞して高給を得てい光。

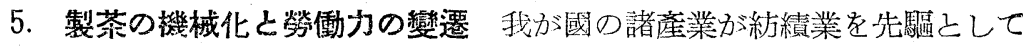
早くも明治20年代に產業革命に進行したのに反し，容易に把握し難い香味や

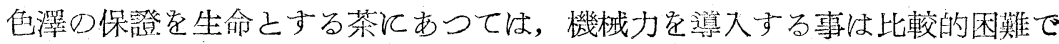
あつて, ために茶業の產業革命は容易に訪れなかつた。殊飞個人的存, 至く 手工的索技術飞依存する程度の强い宇治茶にあつては，機械化の進展は客易 ならす明治40年代の製茶機械の發明移入も何らの影響をく，漸く第一次世界 大戰後の勞兵膫貴が，强固存工場手工的システムの一角定崩し始めたのであ る。かくしてま就煎茶・碾茶の製造に機械が導入され，ついで煎茶園に鋏刈

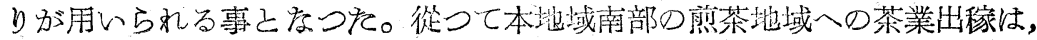


漸次䮠逐されていつた。てれに反し玉露製造の機械化は最も幄れており，こ れが全面的て行かれると至つたのは, 經營面での共同製茶場の钤置同樣, 今 次の戰爭に上る極度の勞力不足に直面してからである。今機械化の現狀をみ るをめ, 昭和17年度の全製茶工場數飞對する機械製茶工場 數の比をるるに (但し牛機恃全機の $1 / 2$ として計算), 宇治郡 $67 \%$ ，久世郡 $73 \%$, 経喜郡 $84 \%$, 相樂郡 $89 \%$ となつ, 北部度に゙立掘れている。高級茶を出す覆下園地域では

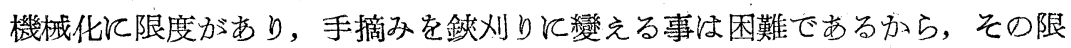
り茶摘みの歌蹈は依然として消え索いであろら。宇治茶生產の產業革命は徐 ふながら進行している。それがいかて労働力に影響しているかは, 何上りも 次の數字名物語つている。

\begin{tabular}{l|crrrr}
\hline & 明治 42 & 大正 2 & 大正 7 & 昭和 3 & 昭和 14 \\
\hline 自家勞力 & 7,976 人 & 7,365 & 6,880 & 約5,500 & 21,856 \\
㕍傭勞力 & 28,141 & 24,295 & 19,836 & 23,491 & 16,780
\end{tabular}

てつに示す雇傭勞力も,「とまりやま」より「通い」に轉じつ」あり, 全體 として出稼人の數は減少している。とにかく宇治茶は停滯的であつて, 明治 40 年飞既飞年產 42 萬貫の生產を示し全國第 3 位であつたが，戰前の最高時之 いえども53萬貫を越えす，今日わすか加26萬貫（昭和21年）程度飞すぎいの

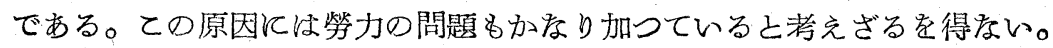

追記 本稿つ大要は太平洋戰爭の終末期に汪心゙完成していたてれ，現狀と多少異

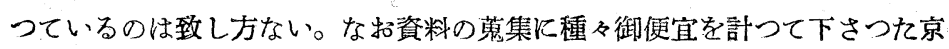
都府茶業聯合會川井課長，並びに地域內町村當局の各位に愿く感謝する。

（昭和24年 5 月 6 日受理） 